\title{
THE SEALS OF THE FALKLAND ISLANDS AND DEPENDENCIES
}

\author{
By R. M. Laws, M.A., Falkland Islands Dependencies Scientific \\ Bureau
}

\section{INTRODUCTION}

The Falkland Islands Dependencies Survey has established and maintained a number of antarctic bases since 1945. They are located on the Graham Land peninsula, in the South Shetland and South Orkney Islands, and at South Georgia ; over the years a great deal of general information about the various species of seals has accumulated. I have spent a total of thirty-six months in the Dependencies between 1948 and 1951 and some weeks in the Falkland Islands, occupied with a special study of the elephant seal, although opportunities were taken for work on other species. As a result we now have a fairly comprehensive picture of the status of the various pinniped species in this sector of the southern oceans.

\section{Former Status and History}

The present status of the southern seals is intimately bound up with commercial sealing operations, both in recent years and during the past 200 years, and a brief survey of the recorded history is called for.

It is not always possible to distinguish between whaling and scaling as two separate specialized occupations during the eighteenth and nineteenth centuries. Whaling ships frequently called at certain islands to augment their cargoes of whale oil with seal oil or skins. Similarly vessels engaged in the elephant oil industry frequently killed sperm and right whales when on passage to and from the seal islands. In general, however, vessels equipped primarily for collecting seal skins did not have the means of carrying out pelagic whaling.

Three species of seals were of commercial importance to these early voyagers. They were the southern fur seal (Arctocephalus australis), the southern sea lion (Otaria byronia), and the southern elephant seal (Mirounga leonina). The sea lion was the least important because of its low oil yield and worthless skin, while the fur seal, owing to its very valuable pelt was of primary importance when the southern sealing fleet was at its peak.

The greater commercial value of the fur seals resulted in their extermination over most of their range within the half-century 
after the remarkable descriptions of Cook and others initiated the southern sealing industry; so that by 1823 the species was virtually extinct. Fanning (1832) mentions that 112,000 fur seal skins were taken in the year 1800 , at South Georgia alone, and Weddell (1825) estimates that 1,200,000 skins had been taken at South Georgia since 1775. The following fifty years saw some rebuilding of the stock but a premature recrudescence of sealing soon reduced it to a handful of survivors. Thus in the 1876 season four ships were only able to take 110 skins, and in 1887 only three skins were taken. It has taken seventy years for the survivors to rebuild the population to the few thousands now existing.

The elephant seal oil industry did not reach its peak until the first decade of the nineteenth century, when the fur seal had ceased to be of primary importance, because the financial returns in proportion to the labour expended were much less remunerative. The decline in numbers also was less rapid than in the case of the fur seal. The elephant seals were pursued sporadically until the 1880's when the numbers had become so small that sealing was unprofitable. By the time that the numbers had again increased sufficiently to justify commercial sealing operations the Government had taken measures to prevent over-exploitation.

The Falkland sea lion never assumed the same commercial importance as the other two species; its range was always more restricted and exploitation limited and sporadic. In recent years, however, it has been the basis of a controlled but short-lived seal oil industry in the Falkland Islands.

Of the antarctic seals only the crabeater has been the object of a commercial expedition. The Dundee whalers and Larsen in the Jason in the 1892-3 season, took some 50,000 adult skins and blubber in the north-west corner of the Weddell Sea.

The wholesale destruction of the southern fur seal between the 1780's and 1822 was the most extravagant and wasteful exploitation of biological resources that has ever occurred, and the species has never recovered from it. Bruce has described this tragedy as " . . . a disaster that should not be forgotten and should, at least, not be allowed to be repeated ".

Present Status of the Species

Southern Fur Seal (Arctocephalus australis).

Owing to the kindness of Mr. P. H. Tilbury, of the South Atlantic Sealing Company, I was able to visit many of the 
breeding stations of the fur seal in the Falkland Islands on the sealing vessel Protector between 17th February and 8th March, 1951. Extracts from my diary follow :-

"At 0715 we were just off Volunteer Rocks, reduced speed and cruised slowly along the south side of the rocks looking for fur seal. Scanning the rocks through field glasses I saw many fur seals silhouetted against the sky and as we approached we heard their clamour and were hit by the smell! There was a 6 -ft. swell but the water was oily-calm, with a tangle of kelp matting the surface near the rocks ... We saw hundreds of fur seal on the second rock including some large pups, which we had heard wailing before we could see them . . . The innermost rock held the greatest number of the beasts, mostly on top of the islet and 20 feet above the sea, but small groups were situated on the shelving sides. Our approach appeared to alarm them greatly and soon fur seals were bounding agilely down to the sea, barking as they went. Once in the watcr they bobbed up and down, swam about rapidly, porpoising most gracefully and showing little fear. Probably there were 2,000 all told, both in the water and on the rocks."

On 21st February, "we passed close to Bird Island, which has high cliffs to the east at the base of which there is a large cave reputed to be the haunt of fur seal. We saw about thirty fur seal on ledges of the cliff just to the north of this cave on the north-east corner of the island. Some were about 30 or 40 feet above sea-level, apparently on a rock face and I was unable to account for it until we had passed and, looking back, I saw the cliff in profile-it rose in a series of rocky ledges. The Manager of Weddell Island, Mr. McGill, whom we picked up later in the day, told me that men used to climb down rope ladders to the caves on Bird Island, kill, and skin the fur seal and carry the skins up on their backs."

On 22nd February we visited the Jason Islands, a chain of small rocky islands set amidst dreadful tide rips and reefs. We made our way past Gibraltar Reef, South Fur Island, and visited North Fur Island and North Fur Rocks, names which reflect the former abundance of the species in the area. But it was only on the virtually inaccessible rocky islets south of Elephant Jason that fur seal were to be seen. "With great excitement we saw that the westerly, and smallest, of the islets was packed with fur seal $-3,000$ was a conservative estimate for the numbers. They were lying on the slopes shelving to the north-east and even on ledges of the steep cliff of the north-west coast. It was impossible to count them for they were closely packed together 
and many must have been out of sight. We hung around the rocks, obtaining very good views of the seals, and discussed ways and means of landing, even seriously considering putting out oil. But the heavy seas from the south swept up both sides of the rocks and it was too risky."

We headed for New Island and landed at the settlement in Ship Harbour on the east coast. Then we walked across to a cove between Precipice Hill and Landsend Bluff. "Scrambling down we found ourselves overlooking some shelving rocks, on which were hauled out over 500 fur seals of all ages. It was a wonderful sight to see these rare animals at close quarters. There were one or two sea lions amongst them. The old 'wig' fur seal were very large, looking like the old 'jaspers' (bull sea lions) except for the shape of the head and the absence of a mane. Many had silvery hair. There were several pups in sight and others, doubtless, in crannies ... The fur seal were very tame and it was only when we dislodged a couple of sea lions, which went into the sea, that they took fright. Even then they played about in the water just off shore, showing no fear. Some of their attitudes were most amusing. They would stand on their heads under water for long periods with only their hind flippers showing ; they floated gracefully and scratched their heads with their hind flippers, or fought each other playfully, barking hoarsely. Others a few hundred yards away on the rocks below Precipice Hill did not move."

We left them and climbed over to Landsend Bluff. Here there is a narrow channel, betwcen a peninsula of the main island and a small island, which has rock cliffs falling vertically, overhanging in parts, to the boiling surf 400 feet below. The island and the neighbouring peninsula are equally precipitous. We traversed a narrow ridge with a $400 \mathrm{ft}$. drop on either side in a gale of sleet and hail which threatened to blow us off. Lying down and peering over the edge I saw an amazing sight. On a small rocky ledge which jutted out from the foot of the cliffs, both immediately below us and on the rocky island, were thousands of fur seal, looking like so many flies. Other smaller ledges higher up were packed tight and seal were even lying in shallow recesses cut out of the rock face by the waves. More seal were playing in the water. Excepting these, there were over 7,000 in the small area we could see. Mr. Davies who farms New Island told me that there are more on North Island, and that he thinks the seal on New Island are an overflow from there.

In addition to these localities fur seal are known to occur in considerable numbers at Beauchene Island, the southernmost 
of the Falkland group. Unfortunately the weather was not suitable for landing there at the time of my visit, but it is reputed to be the largest rookery in the islands. There are also reports of small numbers at Cape Meredith and MacBride Head, which points to an expanding population. We saw an estimated total of 14,000 at the rookeries we visited, and taking into account the estimates of numbers at North Island and Beauchene Islands, there are probably well over 20,000 fur seals in the group as a whole.

The only other known breeding colony of the species in the area is at South Georgia, where, according to local information, there are something like one to three thousand fur seals on Bird Island in the north-west. I was twice prevented from landing there by fog and heavy seas and have not been able to verify this figure. If it is approximately true then a great increase has occurred since an illegal sealer virtually wiped out the South Georgia stock by taking 170 skins in 1906. Thirtyeight were seen at Bird Island in 1933, and twenty-nine at the same localities in 1936, when twelve pups were noted. However, Rankin saw only twenty in 1947 .

It is possible that this colony has begun to overflow to other localities; sealing captains reported the presence ashore of small organized groups in two areas. Fur seals are, however, rarely seen in other parts of the island and it seems that the distribution is very local. That they do undertake extensive pelagic wanderings is beyond reasonable doubt and the recent records of stragglers at the South Orkneys and South Shetlands hold promise of a further extension of their present range and recolonization, in time, of their former breeding localities.

Exploitation theoretically has not taken place for many years, but undoubtedly poachers from South America have made raids. A parcel of some hundreds of skins, almost certainly from the Falkland Islands region, was being processed in the United States not long ago. These skins probably came from Bird Island (Falkland Islands), the most accessible breeding locality, where in 1931 the presence of 750 pups was estimated. In 1951 a search by land and water yielded only twenty-eight pups. We know virtually nothing of the life and habits of the species and exploitation should be postponed at least until this is known in considerable detail. With the introduction of a regular air service between the Islands undetected poaching will be more difficult and there are adequate penalties. In view of the conservative habits of the fur seal it is difficult to say how long the population will take to reach a size when extensive sealing will be justifiable, 
but a further twenty years of protection on which the Government is determined should result in a great increase. The history of conservation of the northern fur seal (Callorhinus alascanus), which admittedly was never reduced to such small numbers nevertheless gives ground for an optimistic view. Reduced by indiscriminate sealing to little more than 150,000 in 1911, and since protected by international treaty, the northern fur seal under rational exploitation now numbers between two and three million animals.

\section{Falkland Sealion (Otaria byronia).}

The sealion has never been subjected to extensive exploitation and is well established in the Falkland Islands. Hamilton (1939) has given a figure of approximately 380,000 for the total numbers in the islands in 1937. Sealing operations in six years between 1928 and 1936 accounted for only 32,183 , and in 1950 to 1951 for about 2,000. There is reason to believe that Hamilton's figure may be too conservative. The reader is referred to his reports for fuller details.

\section{Southern Elephant Seal (Mirounga leonina).}

As a result of recent research at South Georgia and the South Orkney Islands, knowledge of this species is probably second only to that of the northern fur seal among the pinnipeds.

The results of a census in 1951 coupled with what is known of the length of life and reproductive rates, indicates that tinere are at South Georgia 259,000 elephant seals, exclusive of pups of the year. Censuses at the South Orkneys and South Shetlands suggest that at each of these groups of islands there are breeding populations of about 250 animals, and summer visiting populations (presumably from South Georgia) of about 10,000. At the Falkland Islands there are possibly about 1,000 pups born annually representing a breeding population of about 2,600, and a summer influx of about 11,000 animals believed to come from South Georgia.

It was originally thought that the summer populations, which arrive after the breeding season and haul out to moult, were the result of an overflow from the crowded beaches of South Georgia, reflecting the success of the rational control of sealing operations. However, as a result of my observations at South Georgia in 1951 it became apparent that the summer populations in the other three areas represent, in fact, an incipient " refugee" movement caused by over hunting at South Georgia. It is 

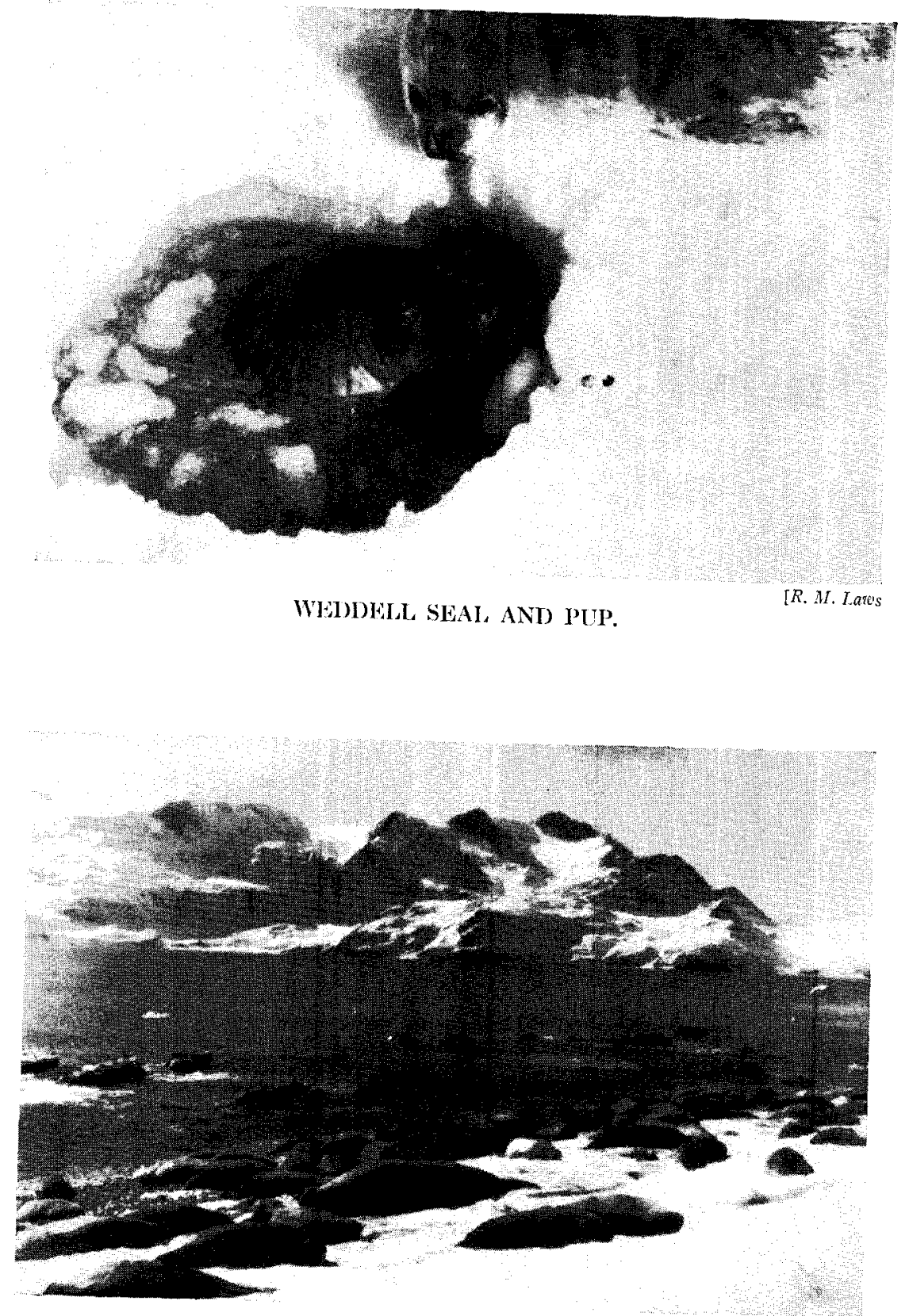

[R. M. Lan's

FLEPHANT SEAISS AT GAST CLNBERLAND BAY. A HAREM BULL 
apposite at this point to outline the control measures which have been in force since 1910 .

The coastline of the island is divided into four areas, three of which are hunted each year while the other is left "fallow". Thus in every fourth year the seals in any particular division are completely undisturbed. Moreover, there are several reserves where seals are never disturbed. Killing is confined to adult males (minimum size undefined), and the sealers are expected to leave 10 per cent on the beaches. The quota taken under government licence, by the Compaña Argentina de Pesca is subject to annual revision, but was stable for many years at 6,000 animals, apportioned equally to the three divisions. In 1948 the quota was increased to 7,500 , and to 8,000 in 1949 , but the sealers have been unable to fill it and the greatest number taken in any one year was 7,877 in 1951 .

It is now apparent that the intensifying of sealing operations has merely served to accentuate the gradual decline of the stock over the past decade or so. It is only in recent years that the decline in numbers has become noticeable and prompt measures should be immediately effective.

Side by side with the decline in numbers there has been a change in the habits of the seals.

(i) The breeding season is now at least a month later in starting than it was in the 1920's.

(ii) The average harem is larger, there being now over forty cows per harem.

(iii) The number of bachelor bulls on land at any one time in the breeding season has been reduced to an average of less than one per harem.

There is, however, reason to believe that the two-year old females (virgins) mate not on land but at sea, and are presumably impregnated by the younger bulls which are more or less unaffected by sealing operations.

The recommendations which have been accepted by the Administration are :-

(i) The annual quota to be restored to 6,000 , and the number taken from each division to be proportional to the estimated population in that division.

(ii) The killing to be confined to males over $3 \frac{1}{2}$ metres long.

(iii) Ten per cent of the bulls over this size to be left on the beaches.

(iv) The lower canine tooth from every twentieth seal killed to be collected and returned to the magistrate. 
At present the average age of the bulls taken is $6 \cdot 6$ years. By means of a simple method of telling the age from growth rings in the teeth (Laws, 1952), and with provision (iv), it will be possible by trial and error over the next few years to fix the average age of the catch at just over $7 \frac{1}{2}$ years. The regulations are, of course, subject to periodic revision.

When the new recommendations are put into practice they should result in an increase in both the population, and therefore in the permissible annual kill, and in the average yield of oil per seal.

In South Georgia during the forty-one years of government control a total recorded catch of 193,384 bull elephant seals was obtained, an average of about 4,700 per year. In the Falkland Islands 3,852 bull elephant seals were taken between 1928 and 1930, and about 900 in 1950 to 1951 . Controlled killing is beneficial to the stock. With a sex ratio at birth of approximately unity, and with the sex ratio of the adults in the harems, nineteen females to one male in an undisturbed population, there is clearly a great excess of males. This leads to fierce and prolonged sexual fighting at the beginning of the breeding season, leading to the death of a high percentage of pups. On reduction of the number of males, other matters being equal, the death rate of the pups is greatly decreased.

\section{The Truly Antarctic Species}

\section{Weddell Seal (Leptonychotes weddelli).}

The scarcity of the weddell seals during the winter months is more apparent than real, for they remain under the sea-ice, keeping open small breathing holes. In the spring and, to a lesser extent, in the summer, they are seen in their thousands around the coasts of the antarctic continent and islands. The females haul out on to the sea ice at the pupping season and give birth to their pups in large scattered rookeries. By the time the young are ready to fend for themselves the fast-ice breaks up and during the summer the weddell population is confined mostly to the ice-floes in inshore waters. 'They tend to be solitary rather than gregarious, and because of this it is unlikely that the weddell seal will be the victim of extensive commercial exploitation. A small industry based upon the pup fur and, in conjunction with the crabeater seal, on the skins and blubber of the adults, may possibly develop. Experiments in the collection and treatment of a small number of pup skins are being made, but any commercial exploitation would be 
limited numerically by the need for keeping the market price of the finished product high. It would be injudicious to flood the market with a large number of skins.

\section{Crabeater Seal (Lobodon carcinophaga).}

The crabeater is essentially an animal of the drifting antarctic pack-ice, one of the most remote parts of the world, and consequently very little is known about its life history. It is seen in numbers only by ships on passage through the pack-ice. Most voyagers in these latitudes have commented on its exceeding abundance in the belt of circumpolar ice. In fact it is probably safe to say that it is the most abundant seal in the world, its numbers exceeding even those of the harp seal (Phoca groenlandica) of arctic seas.

In the Falkland Islands Dependencies the main concentrations of the species are in the Weddell and Bellingshausen seas, to the east and west of the Graham Land peninsula. Moreover, there is some evidence for the existence of two races characterized by different pupping seasons. The west Graham Land animals produce their pups in September, but in the Weddell Sea or further east, the crabeaters may apparently give birth to their pups in March. The evidence for this is provided by photographs taken in March, 1947, by Routh, from the $\mathbf{F} / \mathbf{F}$ Balaena in longitude $85^{\circ} 54^{\prime} \mathrm{E}$.

The crabeater seal would be the primary object of any antarctic sealing industry which might develop in the future. Unfortunately, owing to the attacks of killer whales very few of the animals are free from long raking scars, which renders the skins valueless for leather. Blubber oil would be the objective of the sealers with possibly a limited exploitation of the pup fur.

\section{Leopard Seal (Hydrurga leptonyx).}

The leopard seal is primarily an animal of the pack-ice fringe, where it breeds between September and November, migrating to the subantarctic islands in summer.

It is solitary in disposition and not very abundant. In South Georgia 752 were taken by the sealers from 1910 to 1927 when it was placed on the protected list. Protection was removed in 1951 but because of the low oil yield, the sealers rarely take it. In the Falkland Isiands it has always been subject to persecution because of its supposed ferocity towards man. As a rule it does not attack man unless provoked. 
Because of the protection afforded by its solitary and scattered distribution it is unlikely that the leopard seal is in any danger from commercial exploitation. At the present time probably less than eighty animals of this most interesting species are killed in the Falkland Islands Dependencies each year.

\section{Ross Seal (Ommatophoca rossi).}

The ross seal is the only antarctic seal which is entirely confined to the antarctic seas and has never been recorded from extra-polar regions. Until $\mathbf{1 9 4 5}$ probably less than fifty had ever been seen and it is to be classed as one of the rarest of the pinnipeds. Recent information suggests that it is not so rare as was formerly believed, but that it is very local in distribution. Reports from the Norsel (supply ship of the NorwegianBritish-Swedish Expedition) of groups of ross seal seen between longitudes $5^{\circ} \mathrm{E}$. and $9^{\circ} \mathrm{W}$. total nineteen individuals recorded and probably many more seen but not recorded.

\section{Conclusions}

Very approximate figures for the populations of seal species in the Falkland Islands and Dependencies are set out in Table I, in order to give some idea of the relative numbers. They are in no way definitive, and are only justified because there are no previous figures.

Table 1.-Estimate of Seal Population IN THE FALKIAND ISLANDS AND

DependenCies

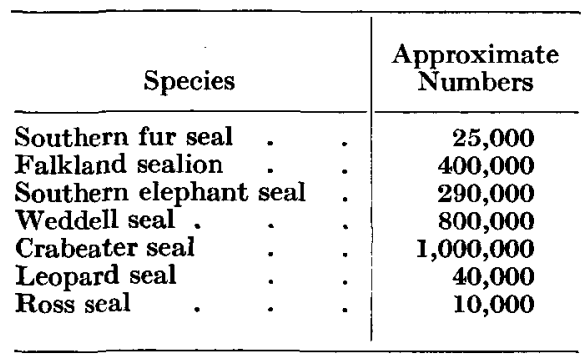

The figures for the populations of the fur seal, sealion, and elephant seal are believed to be reasonably accurate but those for the four other species are little more than guesswork. This applies especially in the case of the crabeater seals and the ross seal ; indeed it is difficult to see how even an approximate estimate of the numbers of these two animals, which are con- 
fined to the pack-ice, is to be obtained. Aerial survey might provide an answer if the weather conditions were not so uniformly bad.

As regards future exploitation there appears to be little danger, in view of the present enlightened attitude of the Government, of any progressive decline in the numbers of any species. We may in fact expect a considerable increase in the stock of the fur seal and the elephant seal, while so far as can be foreseen the populations of the other species will remain stable.

In view of the remote habitats of the antarctic species and the inaccessibility of much of their range of distribution there is little danger of their undue depletion. With the exception of some hundreds killed by polar expeditions for dog food, and the efforts of the Jason expedition, they remain unexploited. Interspecific competition is limited by their diverse feeding habits and geographical distribution, and the populations are almost certainly in a condition of maximum stability. The only two species at all likely to be subjected to commercial exploitation are the crabeater and the weddell. The experience of the Jason and the Norsel indicate that antarctic sealing is quite feasible during the summer months. The Norsel in 1951 took 125 weddells in a few hours.

If large-scale exploitation does occur we must ensure that rational farming resulting from accurate scientific knowledge safeguards these seals from the fate which overtook the fur and elephant seals in the last century.

\section{REFERENCES}

Bertram, G. C. L. B., 1940. The biology of the weddell and crabeater seals. Brit. Grahamland Exp., 1934-7, Sci. Rep. 1, No. 1.

Christie, E. W. H., 1951. The Antarctic Problem. London.

Fanning, E., 1832. Voynges and discoveries in the South Seas. Repr. Mar. Res. Soc., Salem, Mass., 1924.

Hamiton, J. E., 1939. A second report on the southern sealion (Otaria byronia). Discovery Rep., xix, pp. 121-164.

LAws, R. M., 1952. A new method of age determination for mammals. Nature. London, vol. 169, p. 972.

1953. The sealing industry at South Georgia. Polar Record (in Press).

Rankin, N., 1951. Antarctic Isle. Collins, London.

Weddel., J., 1825, A Voyage towards the South Pole performed in the years 1822-3. Longmans, London. 